\title{
Checklist and state of knowledge of helminths in wild birds from Chile: an update
}

\author{
Pablo Oyarzún-Ruiz ${ }^{\mathrm{a}, \mathrm{b}^{*}}$, Daniel González-Acuña ${ }^{\mathrm{a}}$
}

\begin{abstract}
Helminths are an important component of biodiversity with over 24,000 species parasitising wild birds globally, with this figure on the rise given the growing interest in wildlife parasitology. The present study aimed to establish an updated baseline of the helminthological surveys on wild birds from Chile. Available publications were reviewed to build a parasite-host association checklist and also to discuss the state of knowledge regarding these parasites. A total of 92 publications were found between the years 1892 and 2019. Regarding helminth parasites, 174 taxa belonging to 3 phyla and 37 families were recorded, 114 taxa were identified at species level, with the rest remaining incompletely described. Also, 4 taxa corresponded to new genera and 16 to new at species for science. The most reported parasites were platyhelminthes $(53.9 \%)$ followed by nematodes $(36.2 \%)$ and acanthocephalans $(9.2 \%)$. Sixty-five avian species from 19 orders have been recorded as hosts, with most of them having been studied only once (64.6\%). Out of these, the order Charadriiformes had the highest number of publications $(n=23)$. In the case of the avian species present in the country, $14.2 \%$ of native, $40 \%$ of endemic and $22.2 \%$ of exotic species have been recorded hosting helminths. Regarding heteroxenous parasites, only 2 species have had their life cycles elucidated. Among the methodologies used for parasitic identification, $48.9 \%$ of the studies used morphological tools, $5.4 \%$ used molecular tools and $4.3 \%$ used both tools. For that reason, there are evident gaps in the data concerning the hosts sampled, methodologies and issues related to the biology of parasites such as life cycles, among others. In this sense, the need for specialists and cooperative research becomes indispensable to improve our understanding of helminths.

Key words: wildlife, parasitology, helminths, Chile.
\end{abstract}

\section{INTRODUCTION}

Helminths are defined as metazoan parasites including phyla Platyhelminthes (class Cestoda and Trematoda), Nematoda and Acanthocephala, all of them having been reported parasitising wild birds around the world (Wobeser 2008, Roberts et al 2013). Around 24,000 helminth species have been estimated as infecting birds, although this figure could underestimate the real number of parasitic species for this host group (Carlson et al 2019). Thus, these organisms should also be considered as an important component of the biodiversity from any territory (Poulin and Morand 2004).

Helminth parasites can be found not only in the digestive tract but potentially in all tissues, organs, and cavities, depending on the preference for every taxon in every host (Wobeser 2008). The complexity of life cycles varies between different species, with direct or monoxenous life cycles (1 host) and indirect or heteroxenous life cycles (2 or more hosts) (Roberts et al 2013).

Received: Received: 17.03.2020.

Accepted: 24.07.2020.

aLaboratorio de Parásitos y Enfermedades de Fauna Silvestre, Facultad de Ciencias Veterinarias, Universidad de Concepción, Chillán, Chile.

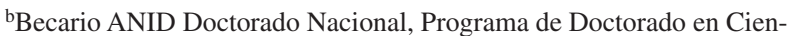
cias Veterinarias, Facultad de Ciencias Veterinarias, Universidad de Concepción, Chillán, Chile.

*Corresponding author: P Oyarzún-Ruiz; Facultad de Ciencias Veterinarias, Universidad de Concepción, Avenida Vicente Méndez 595, Chillán, Chile; pablooyarzunruiz@gmail.com
Parasites from wild birds have been widely studied in Europe and North America providing a vast knowledge of taxonomy, disease, and ecology (Woberser 2008). In South America, the helminth fauna of wild birds have been mostly studied in countries such as Brazil and Argentina with several species and life cycles elucidated thanks to the constant surveys of several groups of local and international parasitologists interested in those hosts (e.g. Lopes et al 2017 a,b, Drago and Lunaschi 2015, Hernández-Orts et al 2019). Notwithstanding the above, the knowledge of helminth parasites in wild birds from Chile is fragmentary, with several avian species without records of its helminth fauna, which could be related to the reduced number of parasitologists performing active research in the country (Hinojosa-Sáez and González-Acuña 2005). The last review on helminth parasites in wild birds from Chile was published by Hinojosa-Sáez and González-Acuña (2005) who reported a total of 49 taxa from all phyla of metazoan parasites parasitising 30 avian species.

Based on a literature review, this study aimed known the number of helminth species parasitising wild birds in Chile and provide a concise description and discussion of the state of knowledge related to parasites, hosts, and methodology used by authors, among others.

\section{MATERIAL AND METHODS}

The present study included literature on helminth fauna of wild birds from Chile and it considered both native and introduced species. A time period between the years 1800 and December 2019 was established. Articles and books were searched through the databases of NCBI, 
Scholar Google, WOS (Web of Science), Scopus and Biodiversity Library (https://www.biodiversitylibrary. org). The following keywords were used in those platforms: helminth, tapeworm, fluke, trematode, Digenea, Nematoda, Acanthocephala, Cestoda, parasite, and avian, using the operator OR between these words together with the word Chile next to the operator AND. Undergraduate theses, technical reports, and scientific meetings do not constitute formal publications (grey literature) and were thus not considered in the present work. Surveys whose location was only stated as "Patagonia", "South America" or "Tierra del Fuego" were also included in this study. The only requirement for those cases was that sampled birds had to be distributed in the country.

The topics considered in every article and book were the following: publications: year and type of publication (book, scientific article); parasites: species, state(s) of development and type of parasitism (natural, experimental); hosts: species, organ(s) parasitised, locality and origin (wild, zoo, rehabilitation centre). Besides, the type of life cycle (direct, indirect or unknown) for recorded helminths was established according to Yamaguti (1958, 1961, 1963), Khalil et al (1994), Anderson (2000) and Moravec (2009). For any new taxa recorded in Chile, a revision of local literature was made to establish its state of knowledge. Additional topics were the area of knowledge, the methodology used for the identification of parasites and the helminthological collections.

The classification of helminths is based on Khalil et al (1994), Gibson et al (2002), Jones et al (2005), Bray et al (2008), Anderson et al (2009), Amin (2013), Roberts et al (2013), Waeschenbach et al (2017) and the databases Global Cestode Database (https://tapeworms. uconn.edu/) and WoRMS (http://www.marinespecies. org/). The taxonomy of avian hosts and also their native, introduced or endemic status followed Avibase (https:// avibase.bsc-eoc.org/avibase.jsp?lang=EN) and Martínez and González (2017). Meanwhile, conservation status for every host was based on the IUCN Red List (https://www. iucnredlist.org/).

A checklist was constructed indicating taxonomy and species of parasites and related hosts ordered alphabetically, state(s) of development for each helminth taxa and organ(s) parasitised, locality and region as a roman number between parenthesis ordered geographically from North to South (i.e., XV=Arica y Parinacota region; I= Tarapacá region; II= Antofagasta region; $\mathrm{III}=$ Atacama region; $\mathrm{IV}=\mathrm{Coquimbo}$ region; $\mathrm{V}=$ Valparaíso region; $\mathrm{RM}=$ Metropolitan region; $\mathrm{VI}=$ Libertador General Bernardo O'Higgins region; $\mathrm{VII}=$ Maule region; $\mathrm{VIII}=$ Bío-Bío region; $\mathrm{XVI}=$ Nuble region; $\mathrm{IX}=$ Araucanía region; $\mathrm{XIV}=\mathrm{Los}$ Ríos region; $\mathrm{X}=\mathrm{Los}$ Lagos region; XI= Aysén del General Carlos Ibáñez del Campo region; $\mathrm{XII}=$ Magallanes y de la Antártica Chilena region), and finally the respective reference. Any requested information not stated by authors was indicated as "Ni" ("Not indicated").

\section{RESULTS}

\section{PUBLICATIONS}

A total of 92 publications ( 88 scientific articles and 4 books) reporting helminths in wild birds from Chile have been published between the years 1896 and December 2019. During that period, and considering the 3 centuries (1800-1899; 1900-1999; 2000-2019), the number of publications per period was 1,44 and 47 , respectively. The highest number of publications was registered between 2011 and 2019, with 26 publications (figure 1).

\section{HELMINTHS TAXA}

One hundred and seventy-four taxa of helminths organised in 3 phyla, 6 classes, 9 orders, 37 families and 95 genera have been found parasitising wild birds in Chile. Out of these taxa, 114 were classified at species level with 4 of them constituting new genera, while 16 are new species. Another 47 helminths were identified at genus level only, 9 at family level, 3 at class and 1 at phylum level. Furthermore, 23 out 47 genera have only been recorded up to this taxonomic level in the country without a specific identification. Other two taxa correspond to accidental parasites of birds: Anisakis sp. and Pseudoterranova sp. A checklist of parasite-host associations is shown in supplementary table $\mathrm{S} 1^{1}$.

When analysing taxa for every phylum, 36.2\% (63/174) belong to Nematoda, $54.6 \%$ (95/174) to Platyhelminthes (52 taxa belonging to class Cestoda and 43 taxa to class Trematoda) and 9.2\% (16/174) to Acanthocephala. Also, $63 \%(58 / 92)$ of publications recorded platyhelminthes, $57.6 \%$ (53/92) nematodes and $18.5 \%$ (17/92) acanthocephalans. Only $33.7 \%$ (31/92) recorded mixed infections between different phyla. About the type of mixed infections, $91.3 \%(84 / 92)$ of the publications recorded natural mixed infections, $14.1 \%$ (13/92) experimental mixed infections and $4.4 \%$ (4/92) had no details on the type of infection.

\section{HOSTS}

A total of 65 species from 19 orders and 32 families of birds were recorded as being parasitised by helminths. Also, 2 birds were not identified at species level, i.e. Larus sp. and Anas sp. A total of 63 bird species were catalogued as native, with 4 of them being also considered as endemic species, while another 2 were catalogued as exotic species. Consequently, and considering the number of avian species present in Chile, 14.2\% (63/443) of native species, $40 \%$ (4/10) of endemic species and $22.2 \%(2 / 9)$ of exotic species have been recorded harbouring helminths to date. With regard to the conservation status of hosts, 57

\footnotetext{
1 Available at: www.australjvs.cl/ajvs
} 


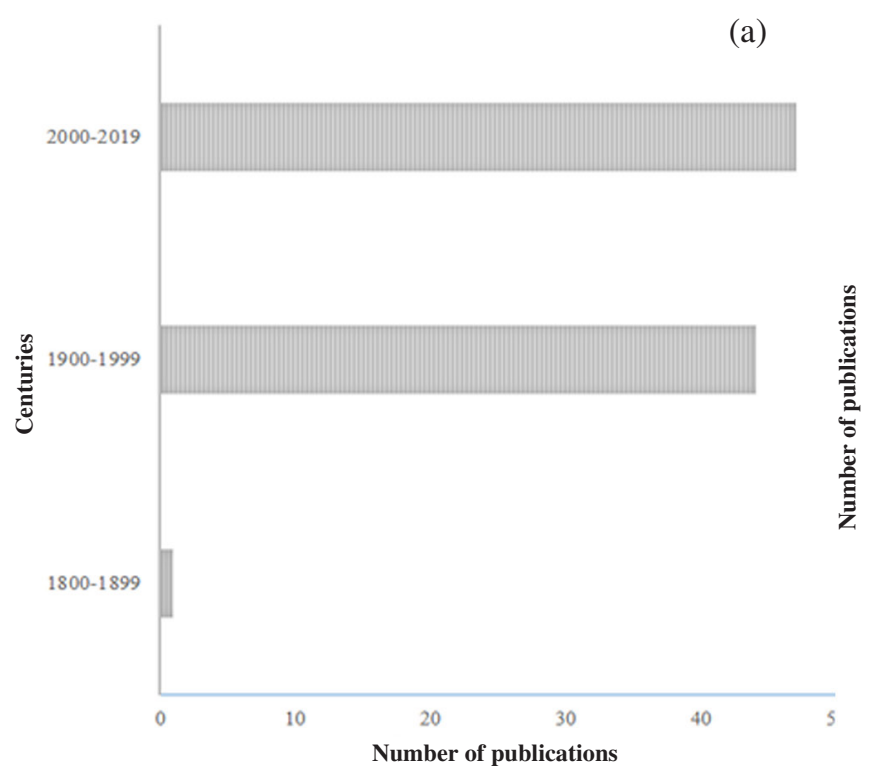

(b)

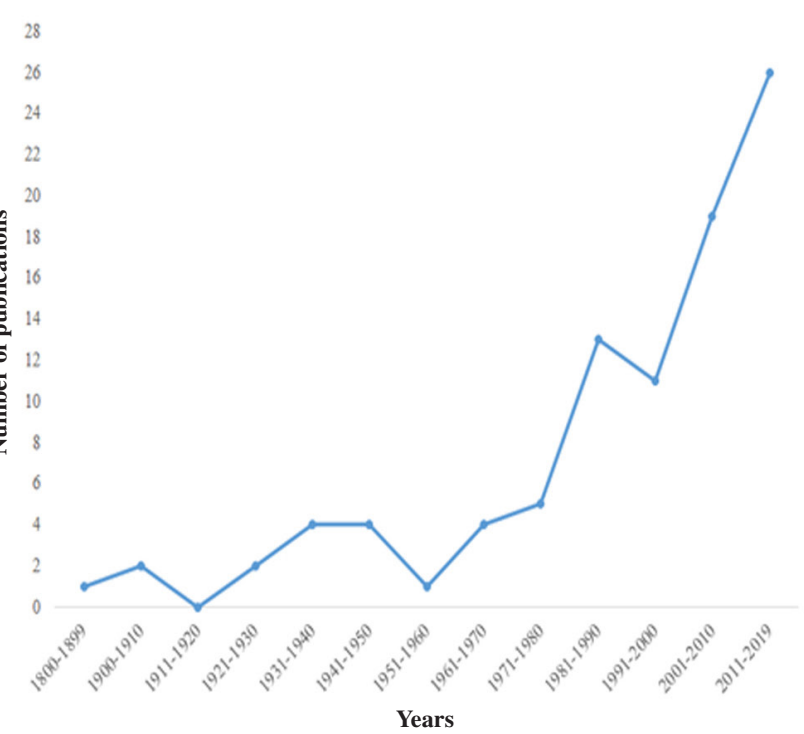

Figure 1. Time scale showing trends in publications regarding helminth fauna in wild birds from Chile. (a) Data organised by centuries from 1800 to the present, and (b) data organised by decades from the year 1900, with only one group for the seventeenth century.

species were classified as Least concern (LC), 3 as Near threatened (NT) and 5 as Vulnerable (VU).

The avian order with the highest number of publications was Charadriiformes $(\mathrm{n}=23)$ followed by Sphenisciformes $(n=14)$, Passeriformes $(n=11)$ and Suliformes $(n=10)$. In the case of the number of species of hosts studied, the order Passeriformes denoted the highest number of publications (13 out 153 species) followed by Charadriiformes (10 out of 81 species). Regarding the number of publications for every avian species, kelp gull (Larus dominicanus) recorded the highest number $(\mathrm{n}=17)$ followed by Brown-hooded gull (Chroicocephalus maculipennis) $(\mathrm{n}=10)$ and the Neotropic cormorant (Phalacrocorax brasilianus) $(\mathrm{n}=8)$. Despite the above-mentioned information, 64.6\% (42/65) of avian hosts have been studied only once.

When considering the origin of birds, $79.4 \%$ (73/92) of publications were based on wild birds, 7.6\% (7/92) came from wildlife rehabilitation centres, 4.4\% (4/92) from zoos and $9.8 \%$ (9/92) of publications did not detail the source.

The analysis of publications covering the subject of infection sites showed that $60.9 \%$ (56/92) of them recorded parasites from the digestive system, $2.2 \%(2 / 92)$ from the respiratory system and 6.5\% (6/92) from other organs/sites (e.g. articulations, blood, bursa of Fabricius, coelomic cavity, pancreas and tendons), where as $34.8 \%$ (32/92) did not detail the organ/tissue.

\section{LIFE CYCLES}

Seventy-four out 114 species have indirect life cycles, 20 have direct life cycles and 20 have unknown life cycles. Two out of 74 heteroxenous species have had their life cycles elucidated in Chile: Profilicollis altma$n i$ and Profilicollis antarcticus. Additionally, there are other 3 heteroxenous helminth species with incomplete knowledge of their life cycles: Dibothriocephalus dendriticus, Stephanoprora uruguayense and Tylodelphys cf. destructor. Considering the 47 parasitic taxa identified only to genus level, 43 of them would have indirect and 4 direct life cycles.

\section{PARASITES BY REGION}

Avian hosts from 12 out of 16 regions of Chile have been recorded as parasitised by helminths. The most studied regions were Los Ríos region (19.6\% of publications, 18/92), Nuble and Biobío regions (16.3\%, $15 / 92$ each one), and Los Lagos region (10.9\%, 10/92). In contrast, wild birds from Tarapacá (I), Atacama (III), Libertador General Bernardo O'Higgins (VI) and Aysén del General Carlos Ibáñez del Campo (XI) regions have not been surveyed for helminths yet. Furthermore, in 15.2\% (14/92) of publications, the authors did not record the locality of collection of birds.

\section{ADDITIONAL INFORMATION}

Although all the publications were based on taxonomy, some of them considered additional focuses, e.g. $6.5 \%$ (6/92) considered pathology and 2.2\% (2/92) had an ecological overview. These views were always combined with taxonomy $(8.7 \%, 8 / 92)$. 


\section{METHODOLOGIES}

The results on the methodology used showed that $48.9 \%(45 / 92)$ of publications used only morphological tools, while $5.4 \%$ (5/92) of surveys used molecular tools with 4 out 5 studies using it together with morphological description. Also, one study was based on the sole use of molecular tools and another used Giemsa stain. Other techniques used with the morphological descriptions of isolated helminths were histopathological analysis with hematoxylin-eosin stain $(6.5 \%, 6 / 92)$ and coproparasitological techniques $(4.4 \%, 4 / 92)$. In contrast, $44.6 \%$ (41/92) of studies did not detail the technique used to identify the parasites. All surveys, except for 1 publication which used only Giemsa stain for blood smear examination, were based on necropsy of birds.

\section{HELMINTHOLOGICAL COLLECTIONS}

Only $45.7 \%$ (42/92) of the studies deposited parasites in a helminthological collection, $21.7 \%$ (20/92) of publications did so in a national collection, $19.6 \%$ (18/92) placed them in an international collection, and $4.4 \%$ (4/92) placed them in both collections. Additionally, only one study out 5 , which used molecular tools, detailed the sequences of the parasites deposited in GenBank.

\section{DISCUSSION}

Since the review by Hinojosa-Sáez and González-Acuña (2005) that was published 14 years ago, a substantial increase in the helminthological knowledge of birds has been recorded until 2019; 49 taxa in the former review versus 174 taxa in this work. This prominent increase could be the consequence of a higher number of publications, i.e. 42 additional scientific articles since 2005, plus another 21 studies that were not considered in the former review (see Lönnberg 1896, Fuhrmann 1908 a, b; Baylis 1928, 1932, Duthoit 1931, Baudet 1937, Porter 1937, Tagle 1942, 1966, Rausch and Morgan 1947, Schuurmans-Stekhoven 1950, Dubois and Rausch 1960, Yamaguti 1963, Szidat 1969, Forrester et al 1978, Torres et al 1981ª $1982^{\mathrm{b}}$, Bartlett and Greiner 1986, McDonald 1988, Wong and Anderson 1991).

The first study reporting helminths in a Chilean wild bird was made by Lönnberg (1896) and the last by Oyarzún-Ruiz et al (2019). On a time scale, the number of publications from the year 2000 to present is higher than that registered during the past century (47 vs 43), which is noteworthy because in 19 years there have been more articles published than in one century. This could be related to a major interest of researchers in this group of hosts.

The increase in the number of species is remarkable as well, from 34 in the former review to 115 species up to 2019. Also, 6 new species were described after the former review was published in the year 2005. In contrast, although there are 16 new species for science described to date, 2 have questionable taxonomic validity, i.e. Contracaecum macronectidis (Schuurmans-Stekhoven 1950) and Taenia diaphoracantha (Fuhrmann 1908b). The first species is the only record of a helminth species for Southern giant-petrel (Macronectes giganteus) from Chile, however, the description was brief and based on one immature worm only, therefore, additional surveys are needed to collect and describe mature worms which are necessary for an accurate identification (see Anderson et al 2009). For the second species, isolated from a Southern rockhopper penguin (Eudyptes chrysocome), it must be noted that the genus Taenia only parasitises mammals as definitive hosts (Khalil et al 1994). Also, the genera Tetrabothrius and Parorchites are the only tapeworms recorded infecting penguins (Brandão et al 2014). The description for $T$. diaphoracantha provided by Fuhrmann $\left(1908^{b}\right)$ detailed several hooks which could be related to genus Parorchites, which is also the only penguin tapeworm with a rostellum (Khalil et al 1994). However, this genus has not been recorded in this penguin, E. chrysocome. On the other hand, the figure of an adult Streptocara sp. from Adelie penguin (Pygoscelis adeliae) by Fredes et al (2008) resembles specimens of Stegophorus spp. with some features that are typical for this genus (e.g. well-developed helmet-like structure with several denticles, thin and long vestibule, and deirids at vestibule-esophagus union) which are absent in Streptocara (see Yamaguti 1961, Anderson et al 2009). For this reason, a revision of the material is needed to establish the identity of these worms.

Furthermore, 23 genera have been recorded only once in Chile, highlighting the need of reviewing the available material and carry out additional surveys to classify these parasites and to determine if they correspond to new species or previously described taxa in other countries, thus amplifying its geographic range to our country.

Anisakis sp. and Pseudoterranova sp. are parasites whose definitive hosts are marine mammals such as cetaceans and pinnipeds meanwhile fishes act as intermediate hosts (Anderson 2000). These nematodes occasionally are found in the stomachs or intestines of wild birds (GeorgeNascimento and Carvajal 1980, Torres et al 2005) which get parasitised through predation of fishes. Only larval stages are found in birds because these nematodes mature exclusively in the former mammals, therefore, birds are considered to be accidental hosts (Anderson 2000).

When considering the total native avifauna from Chile (443 species) (Martínez and González 2017, MMA 2018), it is found that only a few species have been studied for helminthological fauna (14.2\%). Even exotic species lack attention (22.2\%), e.g. the house sparrow (Passer domesticus) and the ring-necked pheasant (Phasianus colchicus) have no published articles regarding endoparasitic fauna. Some possible explanations could be the few groups of parasitologists working on helminths in wildlife in the country. Besides, several avian hosts have restricted distributions in rugged terrain, such as different birds 
that are only present in the highlands (e.g., puna hawk, Geranoaetus poecilochrous) or in Patagonia (e.g., lesser rhea, Rhea pennata pennata) (Martínez and González 2017). Furthermore, 10 avian species are considered endemic in Chile (Martínez and González 2017) and 4 out of them have been studied for helminths. Those studies on endemic species have identified helminth species that seem to be restricted to Chile, with no further records out of the country, e.g., Navonia pterodromae from pink-footed shearwater (Ardenna creatopus) and Juan Fernández petrel (Pterodroma externa) (Diaz et al 2007), and Aploparaksis tinamoui from Chilean tinamou (Nothoprocta perdicaria) (Olsen 1970, Rubilar et al 1996), therefore, they might be considered as endemic parasites. In this way, helminthological studies in the rest of the endemic species could provide similar results, however, the threatened state of conservation of these host populations and their recondite habitats (Martínez and González 2017, MMA 2018) limit the efforts of sampling.

In the case of the avian orders and species, the order Charadriiformes and the kelp gull concentrated most of the published studies, a result similar to that suggested by Hinojosa-Sáez and González-Acuña (2005). In fact, most publications covering this avian order correspond to those on kelp gull (17 out of 23). This could be associated to the wide geographical distribution and population size of this bird in the country, a species with no conservation issues and, consequently, allowed to be captured according to the Hunting Law of the State (SAG 2018).

There are other cases in which certain birds have been surveyed but no helminths have been isolated, such as the Chilean pigeon (Patagioenas araucana) and the invasive monk parakeet (Myiopsitta monachus) (Arriagada et al 2010, Briceño et al 2017). This absence could be the consequence of factors such as the age of birds, necropsy procedure focused only on gastrointestinal parasites or small sample size. Thus, additional surveys including a complete parasitic necropsy are encouraged to determine their helminth fauna in the country. Also, there is an erroneous report by Fuhrmann (1908 $)$ who indicated helminths in a great black-hawk (Buteogallus urubitinga) coming from Chile. However, this species is not distributed in the country but it is found in Central America and Northern Argentina (Ferguson-Lees and Christie 2005).

With regard to infection site in hosts, only three helminth species were recorded as extra-intestinal parasites, i.e. Cyathostoma $(C$.) phenisci infecting the respiratory system (Baudet 1937, Oyarzún-Ruiz et al 2015) and Pelecitus circularis and Pelecitus fulicaeatrae in the joints of birds (Bartlett and Greiner 1986, González-Acuña et al 2017). The reduced record for extra-intestinal parasites could be related to the non-sampling of such organs at the moment of necropsy. For example, Prosthogonimus ovatus, a fluke from the bursa of Fabricius in the Neotropic cormorant, and the avian schistosomes in the blood vessels of kelp gull have been recorded in Argentina (Drago and Lunaschi
2015, Brant et al 2017) but not in Chile. At first, it could be considered that these helminths are not present in the country. However, all studies related to these two birds in Chile have focused only on digestive parasites. In consequence, their presence in the national territory cannot be discarded. Thus, future surveys should consider all organs and tissues as possible habitats of parasites, providing data to increase the number of host-parasite associations and helminth biodiversity for Chile.

As for the species with indirect life cycles, only 2 have known life cycles in the country: Profilicollis altmani with marine birds (Franklin's gull Leucophaeus pipixcan, grey gull Leucophaeus modestus, silvery grebe Podiceps occipitalis, whimbrel Numenius phaeopus, brown-hooded gull and kelp gull) as definitive hosts (Riquelme et al 2006, González-Acuña et al 2017, Rodríguez et al 2017ª) and sandy-shore molecrab Emerita analoga as intermediate host (Jerez et al 2010, Rodríguez et al 2017 a); Profilicollis antarcticus with marine birds (imperial shag Leucocarbo atriceps and kelp gull) as definitive hosts (Torres et al 1991 b 1992 , Rodríguez et al 2017 ${ }^{\mathrm{a}}$ ). On the other hand, there are examples of incomplete known life cycles, e.g. Stephanoprora uruguayense whose definitive hosts in Chile are piscivorous birds (major grebe Podiceps major, Peruvian pelican Pelecanus thagus, brown-hooded gull and kelp gull), and second intermediate hosts are galaxiid fishes (Torres et al 1982a , 1983b, 1991b, 1992, 1993, Viozzi et al 2008). However, the first intermediate host remains unknown. In Argentina, this life cycle was elucidated by Ostrowski de Núñez (2007), indicating the aquatic snail Heleobia parchappei as the first intermediate host. This genus of snail is also present in Chile (Valdovinos 1999), therefore, surveying these mollusks could elucidate the life cycle in the country. Another example is Dibothriocephalus dendriticus whose definitive hosts are gulls (brown-hooded gull and kelp gull) and teleostean fishes (galaxiids, perchs and salmonids) as second intermediate hosts (Muñoz and Olmos 2008), however, the first intermediate host has not been reported. Torres et al (2007) recorded the copepod crustacean Mesocyclops longisetus as the first intermediate host for another broad tapeworm, Dibothriocephalus latus, in Southern Chile. Thus, a relative to these crustaceans, probably, could act as a suitable host as well.

In some cases, there is incomplete identification of larval or adult stages belonging to the same genus, e.g. Wardium spp. and Confluaria spp. The former has been recorded as larvae in the brine shrimp (Artemia persimilis) and adult tapeworm in austral thrushes (Turdus falcklandii). Nevertheless, in both cases there is no species identification (Llanos-Soto et al 2019, Redón et al 2019), therefore, a relationship between both remains uncertain. Furthermore, shorebirds act as definitive hosts as well (Khalil et al 1994). For the second example, this tapeworm has been isolated in the same brine shrimp as Confluaria podicipina, which use grebes as definitive hosts (Redón et al 2019). However, in the silvery grebe from Chile, this 
group has been identified only to genus level (GonzálezAcuña et al 2017). Besides, there are records of larval stages of helminths which use birds as definitive hosts (DH), however, these remain unknown in Chile, e.g. third larval stages of Contracaecum multipapillatum (herons and pelicans as DH) in the flathead grey mullet (Mugil cephalus) (Fernández 1987, Anderson 2000), cystacanths of Profilicollis chasmagnathi (aquatic birds as DH) in estuarine crabs (Rodríguez et al 2017² , Hernández-Orts et al 2019) and cysticercoids of Fimbriarioides sp. (waterfowl and shorebirds as DH) in brine shrimps (Khalil et al 1994, Redón et al 2019). Hereafter, additional surveys on wild hosts incorporating a precise identification of worms through the use of morphological and molecular tools, and also experimental infections, could elucidate the hosts and features of these unknown life cycles in the country (e.g. Ostrowski de Núñez 2007, Rodríguez et al 2017 ).

There is an evident lack of knowledge for newly described species in avian hosts regarding their life cycles in the country with only the avian hosts known to date and no data on the intermediate hosts (heteroxenous life cycles). However, there is a particular case with the possible larval stage isolated reported by Redón et al (2019) who found the larval stage of Flamingolepis in brine shrimp. Hence, this crustacean could act as an intermediate host for Flamingolepis chileno, the only species recorded for this genus in Chile (see supplementary table $\mathrm{S}^{1}$ ).

Although there were other areas of science considered in conjunction with helminthological research, these were just a few; only 2 studies were focused on ecology and other 6 had a pathological focus. In consequence, and considering the importance for understanding the effects of parasitism on wild bird populations (Wobeser 2008), there is a poor understanding of the diverse interactions between helminth fauna and wild birds in Chile. This situation highlights the obvious need for specialists and cooperative work on these and other fields of research, a situation mentioned previously by Hinojosa-Sáez and González-Acuña (2005).

The present review showed that most studies were based on necropsy of birds except for 1 publication which used blood smears for detecting microfilariae (see Forrester et al 1977). Thus, the limits imposed by accessing carcasses in the non-studied birds could be bypassed through their capture with mist nets or sampling captive birds in rehabilitation centres (Lutz et al 2017), without the need to euthanize specimens. In those cases, the collection of faeces would allow the description of digestive, urinary and respiratory helminths through coprological techniques such as simple flotation or modified Baermann technique. However, the limitations of these techniques could be related to the specific identification of parasitic structures, i.e. species, for example (Smith et al 2007). Also, the screening of blood smears should be considered to look for microfilariae, a group of nematodes parasitising various orders of birds around the globe (Bartlett 2008) but with minimal attention here in Chile.

Another taxonomy-related issue recently discussed is the deposition of organisms in accessible collections such as museums, which is also applicable to parasites (Krell 2016). A not negligible percentage of surveys did not specify if isolated helminths were placed in a helminthological collection (53.3\%), including some cases of new species such as Variolepis fernandensis (Nybelin 1929), Notocotylus tachyeretis (Duthoit 1931) and C. (C.) phenisci (Baudet 1937). Moreover, there was a case where material belonged to a private collection (e.g., Tetrabothrius (Neotetrabothrius) eudyptidis (Lönnberg 1896)). The deposition in accessible collections is important particularly for new species, species with conflictive identification as stated in the present review with the helminths $T$. diaphoracantha and $C$. macronectidis, and parasites not completely identified as in the case of the 23 taxa recorded only to genus level, for example. These collections would allow researchers to review material and solve those taxonomical conflicts. In Chile, the only available collection allowing the deposition of helminths is the Museum of Zoology at the Universidad de Concepción, Concepción (see https://www.naturalesudec.cl/zoologia-museo/). For these reasons, we suggest that researchers interested in parasitology should deposit holotypes and paratypes of parasites in this public national collection.

Since parasites are an important component of the biodiversity, although generally neglected by non-parasitologists, research programs should consider parasites as an overall goal in regions considered as hotspots of biodiversity (Poulin and Morand 2004, Mariaux and Georgiev 2018).

As a final recommendation, and considering that there is a conspicuous lack of information mostly related to the methodology, forthcoming researches should fill these voids of data to allow future comprehensive analysis and comparisons related to different species of helminths.

\section{ACKNOWLEDGEMENTS}

\footnotetext{
The first author would like to thank national ANID Doctoral scholarship, Agencia Nacional de Investigación y Desarrollo (ANID), for supporting his doctoral study (scholarship n² 21181059). Daniel González-Acuña is grateful to Proyecto FONDECYT no 1170972 for the financial support. The authors also thank Drs. Mike Kinsella, María Soledad Sepúlveda, Patricio Torres, Javier Paineán, and Paulina Sepúlveda for providing us with bibliography for the present review.
}

\section{REFERENCES}

Amin OM. 2013. Classification of the acanthocephala. Folia Parasitol 60, 273-305.

Anderson RC. 2000. Nematode Parasites of Vertebrates: Their Development and Transmission. $2^{\text {nd }}$ ed. CABI Publishing, Wallingford, UK.

Anderson RC, Chabaud AG, Willmott S. 2009. Keys to the nematode parasites of vertebrates: Archival volume. CAB International, Wallingford, UK. 
Arriagada P, Cicchino A, Mironov S, Ardiles K, Doussang D, et al. 2010. Parasitismo externo y gastrointestinal en torcaza Columba araucana Lesson, 1827 (Aves, Columbidae) de la Comuna de Pinto, Provincia de Nuble, Chile. Parasitol Latinoamericana 69, 158-162.

Aznar FJ, Pérez-Ponce de León G, Raga JA. 2006. Status of Corynosoma (Acanthocephala: Polymorphidae) based on anatomical, ecological, and phylogenetic evidence, with the erection of Pseudocorynosoma n. gen. $J$ Parasitol 92, 548-564.

Azuma H, Okamoto M, Ohbayashi M, Nishine Y, Mukai T. 1988. Cosmocephalus obvelatus (Creplin, 1825) (Nematoda: Acuariidae) collected from the esophagus of rockhopper penguin, Eudyptes crestatus. Jpn J Vet Res 36, 73-77.

Babero B, Cattan P, Jensen L. 1981. Helmintofauna de Chile: IX Flamingolepis chileno sp. n. parásito de Phoenicoparrus andinus Philippi. Boletín del Mus Nac Hist Nat 38, 105-109.

Bartlett CM, Greiner EC. 1986. A revision of Pelecitus Railliet \& Henry, 1910 (Filarioidea, Dirofilariinae) and evidence for the "capture" by mammals of filarioids from birds. Bull du Muséum Natl d'histoire Nat Sect A, Zool Biol écologie Anim 8, 47-99.

Bartlett CM. 2008. Filarioid nematodes. In: Atkinson CT, Thomas NJ, Hunter DB (eds). Parasitic Diseases of Wild Birds. Wiley-Blackwell, Iowa, USA, Pp 439-462.

Baudet EARF. 1937. Cyathostoma phenisci n. sp., parasite de la trachee d'un pingouin. Ann Parasitol Hum Comparée 15, 218-224.

Baylis HA. 1928. A new species of Notocotylus (Trematoda), with some remarks on the genus. J Nat Hist 2, 582-585.

Baylis HA. 1932. A comparison of certain species of the Nematode genus Amidostomum, with a description of a new species. Ann Mag Nat Hist 10, 281-287.

Brandão ML, Moreira J, Luque JL. 2014. Checklist of Platyhelminthes, Acanthocephala, Nematoda and Arthropoda parasitizing penguins of the world. Check List 10, 562-573.

Brant SV, Loker ES, Casalins L, Flores V. 2017. Phylogenetic Placement of a Schistosome from an Unusual Marine Snail Host, the False Limpet (Siphonaria lessoni) and Gulls (Larus dominicanus) from Argentina with a Brief Review of Marine Schistosomes from Snails. J Parasitol 103, 75-82.

Bray RA, Gibson DI, Jones A. 2008. Keys to the Trematoda. Vol. 3. CABI Publishing and The Natural History Museum, London, UK.

Briceño C, Surot D, González-Acuña D, Martínez FJ, Fredes F. 2017. Parasitic survey on introduced monk parakeets (Myiopsitta monachus) in Santiago, Chile. Rev Bras Parasitol Vet 26, 129-135.

Carlson CJ, Phillips AJ, Dallas TA, Alexander LW, Bansal S. 2019. What would it take to describe the global diversity of parasites? PNAS Accepted.

Diaz JI, Sepúlveda MS, Kinsella JM. 2007. A New Genus and Species of Acuarioid Nematode (Acuariidae: Seuratiinae) in Petrels Pterodroma externa and P. neglecta from the Juan Fernandez Islands, Chile. $J$ Parasitol 93, 650-654.

Diaz JI, Fonteneau F, Panisse G, Cremonte F, Navone GT. 2009 Redescription of Ingliseria cirrohamata (Linstow, 1888) (Nematoda: Acuariidae), including new hosts and geographical records. $J$ Parasitol 95, 396-402.

Drago FB, Lunaschi LI, Hinojosa-Saez AC, González-Acuña D. 2007. First record of Australapatemon burti and Paramonostomum pseudalveatum (Digenea) from Anas georgica (Aves, Anseriformes) in Chile. Acta Parasitol 52, 201-205.

Drago FB, Lunaschi LI. 2015. Update of checklist of digenean parasites of wild birds from Argentina, with comments about the extent of their inventory. Neotrop Helminthol 9, 325-350.

Dubois G. 1981. Notes Helminthologiques V: Strigeidae Railliet, Diplostomidae Poirier et Proterodiplostomidae Dubois. Rev Suisse Zool 88, 227-232.

Dubois G, Rausch R. 1960. Quatrième contribution à l'étude des Strigeides (Trematoda) nord-américains. Bull la Société Neuchâteloise des Sci Nat 83, 79-92.
Duthoit CMG. 1931. A new species of the Trematode genus Notocotylus. Ann Mag Nat Hist 7, 290-293.

Ferguson-Lees J, Christie DA. 2005. Raptors of the World. Princeton University Press, New Jersey, USA.

Fernández Í, Moraga R, Yáñez F, Mansilla M, Smith C, et al. 2019. Gastrointestinal helminths of Humboldt penguin (Spheniscus humboldti Meyen, 1834) from south central Chile. Lat Am J Aquat Res 47, 206-211.

Fernández J. 1987. Los parásitos de la lisa Mugil cephalus L. en Chile: sistemática y aspectos poblacionales (Perciformes: Mugilidae). Gayana Zool 51, 3-58.

Figueroa L, Torres P, Schlatter R, Asenjo F, Franjola R, et al. 1979. Investigaciones sobre Pseudophyllidea (Carus 1813) en el sur de Chile. III. Estudio sobre Diphyllobothrium sp. en aves del lago Calafquén ( $\left.39^{\circ} 32^{\prime} \mathrm{S}-72^{\circ} 09^{\prime} \mathrm{O}\right)$. Boletín Chil Parasitol 34, 13-20.

Figueroa L, Torres P, Franjola R, Schlatter R. 1980. Investigaciones sobre Pseudophyllidea (Carus, 1813) en el sur de Chile. VI. Infección por Diphyllobothrium (Cobbold) en Larus maculipennis Lichtenstein en el Lago Calafquén. Boletín Chil Parasitol 35, 71-73.

Forrester DJ, Greiner EC, McFarlane RW. 1977. Blood parasites of some Columbiform and Passeriform birds from Chile. J Wildl Dis 13, 94-96.

Fredes F, Raffo E, Muñoz P, Herrera M. 2006. Fauna parasitaria gastrointestinal en polluelos de Pingüino Papua (Pygoscelis papua) encontrados muertos en zona antártica especialmente protegida (ZAEP N $\left.{ }^{\circ} 150\right)$. Parasitol Latinoam 61,179-182.

Fredes F, Madariaga C, Raffo E, Valencia J, Herrera M, et al. 2007. Gastrointestinal parasite fauna of gentoo penguins (Pygoscelis рариа) from the Península Munita, Bahía Paraíso, Antarctica. Antarct Sci 19, 93-94.

Fredes F, Raffo E, Muñoz P, Herrera M, Godoy C. 2008. Fauna parasitaria gastrointestinal en el pingüino Adelia (Pygoscelis adeliae) de zona antártica especialmente protegida (ZAEP $\left.\mathrm{N}^{\circ} 150\right)$. Parasitol Latinoam 63, 64-68.

Fuentes D, Reyes J, Sepúlveda MS, Kinsella M, Mironov SV, et al. 2015. Gastrointestinal and external parasites of the White-crested elaenia Elaenia albiceps chilensis (Aves, Tyrannidae) in Chile. Braz J Vet Parasitol 24, 276-282.

Fuhrmann O. 1908'a . Die Cestoden der vögel. Zool Jahrbücher 10, 1-232. Fuhrmann O. 1908 . Nouveaux Ténias d'Oiseaux. Rev Suisse Zool 16, $27-73$.

Garbin L, Mattiucci S, Paoletti M, González-Acuña D, Nascetti G. 2011. Genetic and morphological evidences for the existence of a new species of Contracaecum (Nematoda: Anisakidae) parasite of Phalacrocorax brasilianus (Gmelin) from Chile and its genetic relationships with congeners from fish-eating birds. J Parasitol 97, 476-492.

Gay C. 1849. Historia física y política de Chile - Zoología, Tomo Tercero. Imprenta de Maulde y Benou, Paris, Francia.

George-Nascimento M, Carvajal J. 1980. Nuevos registros de nematodos anisákidos en la fauna marina chilena. Boletín Chil Parasitol 35, 15-18.

Gibson DI, Jones A, Bray RA. 2002. Keys to the Trematoda, Volume 1. CABI Publishing and The Natural History Museum, London, UK.

González H, Garrido V, Landeta ME, Martens P. 1980. Nuevos aportes para la identificación de Diphyllobothrium sp., en el lago Rupanco, Chile. Boletín Chil Parasitol 35, 10-14.

González D, Castillo G, López J, Moreno L, Donoso S, et al. 2004a . Parásitos Gastrointestinales y Externos de la Paloma Doméstica (Columba livia) en la Ciudad de Chillán, Chile. Agrociencia 20, 107-112.

González D, Daugschies A, Rubilar L, Pohlmeyer K, Skewes O, et al. $2004^{b}$. Fauna parasitaria de la tórtola común (Zenaida auriculata, de Murs 1847) (Columbiformes: Columbidae) en Ñuble, Chile. Parasitol Latinoam 59, 37-41.

González D, Skewes O, Candia C, Palma R, Moreno L. 2005. Estudio del parasitismo gastrointestinal y externo en caiquén Chloephaga picta Gmelin, 1789 (Aves, Anatidae) en la región de Magallanes, Chile. Parasitol Latinoam 60, 86-89. 
González-Acuña D, Skewes-Ramm O, Rubilar-Contreras L, Daugschies A, Pohlmeyer K. 2000. Endoparásitos de codorniz (Callipepla californica) en Nuble (Chile). Boletín Chil Ornitol 7, 23-25.

González-Acuña D, Fabry M, Nascimento AA, Tebaldi JH. 2007. Death of two slender-billed parakeet (King) (Enicognathus leptorhynchus) (Aves, Psittacidae) by Ascaridia hermaphrodita (Froelich, 1789, Railliet \& Henry, 1914) at the National Zoo of Santiago, Chile. Arq Bras Med Vet e Zootec 59, 539-540.

González-Acuña D, Olmedo P, Cicchino A. 2008ª . Parásitos de Vanellus chilensis (Aves, Charadriidae) en Chillán, Centrosur de Chile. Boletín Chil Ornitol 14, 36-48.

González-Acuña D, Kinsella JM, Lara J, Valenzuela-Dellarossa G. 2008 . Parásitos gastrointestinales en pinguino de Humbolt (Spheniscus humboldti) y pinguino de Magallanes (Spheniscus magellanicus) en las costas del centro y centro sur de Chile. Parasitol Latinoam 63, 58-63.

González-Acuña D, Cerda F, López J, Ortega R, Mathieu C, et al. 2009. Checklist of the helminths of the kelp gull, Larus dominicanus (Aves: Laridae), with new records from Chile. Zootaxa 2297, 27-43.

González-Acuña D, Moreno L, Cicchino A, Mironov S, Kinsella M. 2010. Checklist of the parasites of the black-necked swan, Cygnus melanocoryphus (Aves: Anatidae), with new records from Chile. Zootaxa 2637, 55-68.

González-Acuña D, Lohse E, Cicchino A, Mironov S, Figueroa RA, et al. 2011 ${ }^{\mathrm{a}}$. Parasites of the American Kestrel (Falco sparverius) in South-Central Chile. J Raptor Res 45, 188-193.

González-Acuña D, Silva C, Soto M, Mironov S, Moreno L, et al. $2011^{\text {b }}$ Parasites of the Green-backed Firecrown (Sephanoides sephaniodes) in Chile. Rev Mex Biodivers 82, 1333-1336.

González-Acuña D, Hernández J, Moreno L, Herrmann B, Palma R, et al. 2013. Health evaluation of wild gentoo penguins (Pygoscelis papua) in the Antarctic Peninsula. Polar Biol 36, 1749-1760.

González-Acuña D, Llanos-Soto S, Landaeta-Aqueveque C, González F, Kinsella JM, et al. 2017. Parasites of the Southern silvery grebe Podiceps occipitalis (Aves, Podicipedidae) in Chile. Braz J Vet Parasitol 26, 378-382.

Grandón-Ojeda A, Valdebenito JO, Moreno L, Kinsella JM, Mironov S, et al. 2018. Gastrointestinal and external parasitism in the Magellanic Horned Owl Bubo magellanicus (Strigiformes: Strigidae) in Chile. Braz J Vet Parasitol 27, 161-168.

Grandón-Ojeda A, Cortés P, Moreno L, Kinsella JM, Cicchino A, et al. 2019. Gastrointestinal and external parasites of the Variable hawk Geranoaetus polyosoma (Accipitriformes: Accipitridae) in Chile. Braz J Vet Parasitol 28, 376-382.

Hernández-Orts JS, Kuchta R, Semenas L, Crespo EA, González RA, et al. 2019. An annotated list of the Acanthocephala from Argentina. Zootaxa 4663, 1-64.

Hinojosa-Sáez A, González-Acuña D. 2005. Estado actual del conocimiento de helmintos en aves silvestres de Chile. Gayana 69, 241-253.

Hinojosa-Sáez A, González-Acuña D, George-Nascimento M. 2009. Parásitos metazoos de Anas georgica Gmelin, 1789 (Aves: Anseriformes) en Chile central: especificidad, prevalencia y variaciones entre localidades. Rev Chil Hist Nat 82, 337-345.

Housse PR. 1945. Las aves de Chile, su vida y costumbres. Editorial Universidad de Chile, Santiago, Chile.

Jerez R, George-Nascimento M. 2010. Asociación del parasitismo por Profilicollis bullocki (Paleacanthocephala, Polymorphidae) con la conducta y la pigmentación de Emerita analoga (Anomura, Hippidae) en Chile. Rev Biol Mar Oceanogr 45, 525-529.

Jones A, Bray RA, Gibson DI. 2005. Keys to the Trematoda, Volume 2. CABI Publishing and The Natural History Museum, London, UK.

Khalil L, Jones A, Bray R. 1994. Keys to the Cestode parasite of Vertebrates. CAB International, London, UK.

Krell FT. 2016. Taxonomy: Preserve specimens for reproducibility. Nature 539, 168

Leiva N, George-Nascimento M, Muñoz G. 2015. Carga parasitaria en crustáceos decápodos de la costa central de Chile: ¿existe alguna asociación con la abundancia de los hospedadores definitivos? Lat Am J Aquat Res 43, 726-738.

Leiva NV, López Z, González MT, Muñoz G. 2017. Determining Intermediate Hosts for Opecoelidae and Microphallidae Species (Platyhelminthes: Trematoda) in the Southeastern Pacific Coast, Using Molecular Markers. J Parasitol 103, 132-137.

Llanos-Soto S, Muñoz B, Moreno L, Landaeta-Aqueveque C, Kinsella JM, et al. 2017. External and gastrointestinal parasites of the rufous-collared sparrow Zonotrichia capensis (Passeriformes, Emberizidae) in Chile. Braz J Vet Parasitol 26, 314-322.

Llanos-Soto S, Córdoba M, Moreno L, Kinsella JM, Mironov S, et al. 2019. External and intestinal parasites of the Austral thrush Turdus falcklandii (Aves, Turdidae) in central Chile. Braz J Vet Parasitol 28, 432-442.

Lönnberg E. 1896. Cestoden. In: Lönnberg E (ed). Ergebnisse der Hamburger Magalhaensischen Sammelreise III. Band. Bryozoen und Würmer. L. Friederichsen \& Co., Hamburg, Germany, Pp 1-9.

Lopes DA, Gomes DC, Knoff M. 2017 a Type material of Acanthocephala, Nematoda and other non-helminths phyla (Cnidaria, Annelida, and Arthropoda) housed in the Helminthological Collection of the Oswaldo Cruz Institute/ FIOCRUZ (CHIOC), Rio de Janeiro, Brazil, from 1979 to 2016. Zookeys 711, 1-52.

Lopes DA, Mainenti A, Knoff M, Gomes DC. 2017b. Type material of Platyhelminthes housed in the Helminthological collection of the Oswaldo Cruz Institute/ FIOCRUZ (CHIOC), Rio de Janeiro, Brazil, from 1979 to 2016 (Rhabditophora, Trematoda and Cestoda). Zookeys 662, 1-48.

Lutz HL, Tkach VV, Weckstein JD. 2017. Methods for Specimen-based Studies of Avian Symbionts. In: Webster MS (ed). The Extended Specimen: Emerging Frontiers in Collections-based Ornithological Research. CRC Press, Boca Raton, FL, USA, Pp 157-183.

Mariaux J, Georgiev BB. 2018. Bird cestodes from Huinay (Comau Fjord), Chilean Patagonia: several species of the family Dilepididae (Platyhelminthes, Cyclophyllidea), with the erection of two new genera. Zookeys 797, 1-18.

Martínez D, González G. 2017. Aves De Chile: Guía de Campo y breve Historia Natural. Ediciones del Naturalista, Santiago, Chile.

McDonald M. 1988. Key to acanthocephala reported in waterfowl. U.S. Fish and Wildlife Service, Washington D.C., USA.

MMA, Ministerio de Medio Ambiente. 2018. Biodiversidad de Chile: Patrimonio y desafíos, Tomo I. Tercera ed. Ministerio de Medio Ambiente, Santiago, Chile.

Moravec F. 2009. Experimental studies on the development of Contracaecum rudolphii (Nematoda: Anisakidae) in copepod and fish paratenic hosts. Folia Parasitol 56, 185-193.

Muñoz G, Olmos V. 2008. Revisión bibliográfica de especies endoparásitas y hospedadoras de sistemas acuáticos de Chile. Rev Biol Mar Oceanogr 43, 173-245.

Nybelin O. 1929. Säugetier- und Vogelcestoden von Juan Fernandez. Nat Hist Juan Fernandez Easter Isl 3, 493-523.

Olsen OW. 1970. Aploparaksis tinamoui n. sp. Cestode (Hymenolepididae) from the chilean Tinamou (Notroprocta perdicaria (Kittlitz, 1830) Tinaniformes). Rev Ibérica Parasitol 30, 701-718.

Ostrowski de Núñez M, Flores V, Viozzi G, Kreiter A. 2004. Stephanoprora uruguayense Holcman-Spector et Olagüe, 1989 (Digenea, Echinostomatidae) from Argentina, and comments on species of Stephanoprora from birds of the Neotropical Region. Acta Parasitol 49, 292-299.

Ostrowski de Núñez M. 2007. Life cycle of Stephanoprora uruguayense (Digenea: Echinostomatidae) in Argentina. J Parasitol 93, 1090-1096.

Oyarzún-Ruiz P, Muñoz-Alvarado P. 2015. Cormorán imperial, Phalacrocorax atriceps (Aves, Phalacrocoracidae): Nuevo hospedero para un parásito respiratorio, Cyathostoma (Cyathostoma) phenisci (Nematoda, Syngamidae). Rev Biol Mar Oceanogr 50, 353-358.

Oyarzún-Ruiz P, Muñoz-Alvarado P, Raffo E. 2016. Helminths of Milvago chimango temucoensis (Aves: Falconiformes) from Los Ríos Region, 
Chile: New Records for Neotropical Raptors. Helminthologia 53, 336-353.

Oyarzún-Ruiz P, Muñoz P, Paredes E, Valenzuela G, Ruiz J. 2019. Gastrointestinal helminths and related histopathological lesions in black-necked swans Cygnus melancoryphus from the Carlos Anwandter Nature Sanctuary, Southern Chile. Braz J Vet Parasitol $28,613-624$.

Paré JA, Black SR. 1999. Schistosomiasis in a collection of captive Chilean flamingos (Phoenicopterus chilensis). J Avian Med Surg 13, 187-191.

Phillips AJ, Georgiev BB, Waeschenbach A, Mariaux J. 2014. Two new and two redescribed species of Anonchotaenia (Cestoda: Paruterinidae) from South American birds. Folia Parasitol 61, 441-461.

Porter CE. 1937. Notas de parasitología. Rev Chil Hist Nat 41, 77.

Poulin R, Morand S. 2004. Parasite Biodiversity. Smithsonian Books, Washington D.C., USA.

Pulgar J, Aldana M, Vergara E, George-Nascimento M. 1995. La conducta de la jaiba estuarina Hemigrapsus crenulatus (Milne-Edwards 1837) en relación al parasitismo por el acantocéfalo Profilicollis antarcticus (Zdzitowiecki 1985) en el sur de Chile. Rev Chil Hist Nat 68, 439-450.

Rausch R, Morgan BB. 1947. The genus Anonchotaenia (Cestoda: Dilepididae) from North American birds, with the description of a new species. Trans Am Microsc Soc 66, 203-211.

Redón S, Vasileva GP, Georgiev BB, Gajardo G. 2019. First report of cestode infection in the crustacean Artemia persimilis from Southern Chilean Patagonia and its relation with the Neotropical aquatic birds. PeerJ 7, e7395.

Riquelme C, George-Nascimento M, Balboa L. 2006. Morfometría y fecundidad de Profilicollis bullocki Mateo, Córdova \& Guzmán 1982 (Acanthocephala: Polymorphidae) en especies simpátricas de aves costeras de Chile. Rev Chil Hist Nat 79, 465-474.

Roberts LS, Janovy Jr J, Nadler S. 2013. Foundations of Parasitology. $9^{\text {th }}$ ed. McGraw-Hill Company, New York, USA.

Rodríguez SM, D’Elía G, Valdivia N. 2017 . The phylogeny and life cycle of two species of Profilicollis (Acanthocephala: Polymorphidae) in marine hosts off the Pacific coast of Chile. J Helminthol 91, 589-596.

Rodríguez SM, Diaz JI, D’Elía G. 2017 . Morphological and molecular evidence on the existence of a single estuarine and rocky intertidal acanthocephalan species of Profilicollis Meyer, 1931 (Acanthocephala: Polymorphidae) along the Atlantic and Pacific coasts of southern South America. Syst Parasitol 94, 527-533.

Rubilar L, Bertossi E, Skewes O. 1996. Parasitismo gastrointestinal en la perdiz común (Nothoprocta perdicaria) en la zona de Nuble, Chile. Boletín Chil Parasitol 51, 35-37.

SAG. 2018. Ley $N^{\circ} 19.473$ y su Reglamento. Servicio Agrícola y Ganadero, Santiago, Chile

San Martín J, Brevis C, Rubilar L, Krone O, González-Acuña D. 2006. Parasitismo gastrointestinal en tiuque común Milvago chimango chimango (Vieillot, 1816) (Aves, Falconidae) en Nuble, Chile. Parasitol Latinoam 6, 63-68.

San Martín-Órdenes JA. 2009. Diversidad de Trichinelloidea (Enoplea, Nematoda) en Chile y su implicancia en salud humana, animal y ecosistémica. Lundiana 10, 19-52.

Schlatter RP, Salazar J, Villa A, Meza J. 1991. Reproductive biology of black-necked swans Cygnus melancoryphus at three Chilean wetland areas and feeding ecology at Rio Cruces. Wildfowl 42, 268-271.

Schuurmans-Stekhoven JH. 1950. Nematodos parasitarios del Chaco Paraguayo y de Argentina del Museo de Estocolmo. Acta zoológica Lilloana 9, 325-345.

Seguel M, González-Acuña D, Mathieu C, Hernández C, Paredes E. 2012. Immunosuppressive Syndrome in Juvenile Black-Faced Ibises (Theristicus melanopis melanopis) in Southern Chile. Avian Dis 56, 611-615.

Smith PH, Wiles SE, Malone Jr JB, Monahan CM. 2007. Collection, Preservation, and Diagnostic Methods. In: Baker DG (ed). Flynn's Parasites of Laboratory Animals. Blackwell Publishing, Iowa, USA.
Soto M, Moreno L, Sepúlveda MS, Kinsella JM, Mironov S, et al. 2013. First records of parasites from the Long-tailed Meadowlark Sturnella loyca (Passeriformes: Icteridae) from the Biobío Region, Chile. Rev Mex Biodivers 84, 1316-1320.

Szidat L. 1969. Structure, Development, and Behaviour of New Strigeatoid Metacercariae from Subtropical Fishes of South America. J Fish Res Board Canada 26, 753-786.

Tagle I. 1942. Parásitos de los animales domésticos en Chile determinados en el Instituto de Investigaciones Veterinarias. Agric Técnica 13, 93-108.

Tagle I. 1966. Parásitos de los animales domésticos en Chile. Boletín Chil Parasitol 21, 118-123.

Toro H, Saucedo C, Borie C, Gough RE, Alcaino H. 1999. Health status of free-living pigeons in the city of Santiago. Avian Pathol 28, 619-623.

Torres P, Figueroa L, Franjola R. 1981 a. Investigaciones sobre Pseudophyllidea (Carus, 1813) en el sur de Chile. VIII. Desarrollo experimental de Diphyllobothrium dendriticum Nitzsch en Larus maculipennis Lichtenstein. Boletín Chil Parasitol 36, 74-75.

Torres P, Franjola R, Figueroa L, Schlatter R, González H, et al. 1981 . Researches on Pseudophyllidea (Carus, 1813) in the south of Chile. IV Occurrence of Diphyllobothrium dendriticum (Nitzch). J Helminthol 55, 173-188.

Torres P, Figueroa L, Saldivia A, Barrientos J. 1982a . Gastrointestinal Helminths of Fish-eating birds from the Valdivia River, Chile. $J$ Parasitol 68, 1157.

Torres P, Franjola R, Figueroa L, Contreras B. 1982 ${ }^{\text {b }}$. Pseudophyllidea (Carus, 1813) en el sur de Chile: VII. Distribución estacional de la infección por plerocercoides en Salmo gairdneri (Richardson) del lago Calafquén. J Vet Med Ser B 29, 67-75.

Torres P, Sierpe V, Schlatter R. 1983a . Occurrence of Contracaecum rudolphii in New Hosts in Chile. Zeitschrift für Parasitenkd 69, 397-399.

Torres P, Figueroa L, Saldivia A. 1983 ${ }^{\mathrm{b}}$. Stephanoprora denticulata (Trematoda, Echinostomatidae) en gaviotas del sur de Chile. Boletín Chil Parasitol 38, 33-34.

Torres P, Torres J, Garrido O, Thibaut J. 1989. Investigaciones sobre Pseudophyllidea (Carus, 1813) en el sur de Chile. X. Observaciones experimentales sobre la coexistencia de plerocercoides de Diphyllobothrium latum (L.) y D. dendriticum (Nitzch) en salmónidos de la cuenca del río Valdivia. Arch Med Vet 21, 51-57.

Torres P, Cubillos V, Gesche W, Rebolledo C, Montefusco A, et al. $1991^{\text {a }}$. Difilobotriasis en salmónidos introducidos en lagos del sur de Chile: Aspectos patológicos, relación con infección humana, animales domésticos y aves piscívoras. Arch Med Vet 23, 165-183.

Torres P, Ruiz E, Gesche W, Montefusco A. 1991 . Gastrointestinal helminths of fish-eating birds from Chiloe Island, Chile. $J$ Wildl Dis 27, 178-179.

Torres P, Contreras A, Cubillos V, Gesche W, Montefusco A, et al. 1992. Parasitismo en peces, aves piscívoras y comunidades humanas ribereñas de los lagos Yelcho y Tagua-Tagua, X Región de Chile. Arch Med Vet 24, 77-92.

Torres P, Schlatter R, Montefusco A, Gesche W, Ruiz E, et al. 1993. Helminth parasites of piscivorous birds from lakes in the south of Chile. Mem Inst Oswaldo Cruz 88, 341-343.

Torres P, Valdivieso J, Schlatter R, Montefusco A, Revenga J, et al. 2000. Infection by Contracaecum rudolphii (Nematoda: Anisakidae) in the Neotropic cormorant Phalacrocorax brasilianus, and fishes from the estuary of the Valdivia river, Chile. Stud Neotrop Fauna Environ 35, 101-108.

Torres P, Ortega J, Schlatter R. 2005. Nematode parasites of the digestive tract in Neotropic cormorant chicks (Phalacrocorax brasilianus) from the River Cruces Ramsar site in southern Chile. Parasitol Res 97, 103-107.

Torres P, Villalobos L, Woelfl S. 2007. Experimental infection of copepods from four lakes in southern Chile with Diphyllobothrium latum (Linnaeus, 1758) Coracidia. Comp Parasitol 74, 167-170.

Valdebenito JO, Moreno L, Landaeta-Aqueveque C, Kinsella JM, Mironov S, et al. 2015. Gastrointestinal and external parasites of 
Enicognathus ferrugineus and Enicognathus leptorhynchus (Aves, Psittacidae) in Chile. Braz J Vet Parasitol 24, 422-431.

Valdebenito JO, Moreno L, Barrientos C, Mironov S, Kinsella JM, et al. 2018. Gastrointestinal and ectoparasites of plumbeous rail, Pardirallus sanguinolentus (Aves: Rallidae) in Central Chile. Braz. $J$ Vet Parasitol 27, 301-312.

Valdovinos C. 1999. Biodiversidad de moluscos chilenos: base de datos taxonómica y distribucional. Gayana 63, 111-164.

Valenzuela G, Araya A, Oyarzún-Ruiz P, Muñoz P. 2018. Helmintofauna del cisne de cuello negro Cygnus melancoryphus (Aves: Anatidae) del Santuario de la Naturaleza Carlos Anwandter, Valdivia, Chile. Rev Mex Biodivers 89, 568-571.

Viozzi G, Flores V, Marín SL, Mancilla M, Carvajal J. 2008. Parasites of the Red Jollytail, Brachygalaxias bullocki (Osmeriformes: Galaxiidae), from the Maullín River, Patagonia, Chile. Comp Parasitol 75, 326-328.

Waeschenbach A, Brabec J, Scholz T, Littlewood DTJ, Kuchta R. 2017. The catholic taste of broad tapeworms - multiple routes to human infection. Australian Society for Parasitology. Int J Parasitol 47, 831-843.

Widmer V, Georgiev B, Mariaux J. 2013. A new genus of the family Hymenolepididae (Cestoda) from Sephanoides sephaniodes (Apodiformes, Trochilidae) in Northern Patagonia (Chile). Acta Parasitol 58, 105-111.
Wobeser G. 2008. Parasitism: Costs and Effects. In: Atkinson C, Thomas N, Hunter D (eds). Parasitic Diseases of Wild Birds. Wiley-Blackwell, Iowa, USA.

Wong PL, Anderson RC. 1990. Host and geographic-distribution of Skrjabinoclava spp. (Nematoda: Acuarioidea) in nearctic shorebirds (Aves: Charadriiformes), and evidence for transmission in marine habitats in staging and wintering areas. Can J Zool 68, 2539-2552.

Wong PL, Anderson RC. 1991. Distribution of gizzard nematodes (Habronematoidea, Acuarioidea) of New World shorebirds (Charadriiformes), with special reference to localities of transmission. Can J Zool 69, 2579-2588.

Yamaguti S. 1958. Systema Helminthum Volume IThe Digenetic Trematodes of Vertebrates. Interscience Publishers Inc., New York, USA.

Yamaguti S. 1961. Systema Helminthum Volume III The Nematodes of Vertebrates. Interscience Publishers Inc., New York, USA.

Yamaguti S. 1963. Systema Helminthum Volume V Acanthocephala. Interscience Publishers Inc., New York, USA.

Yáñez F, Fernández Í, Campos V, Mansilla M, Valenzuela A, et al. 2012. First pathological report of parasitic gastric ulceration in Humboldt penguin (Spheniscus humboldti) along the coast of south-central Chile. Lat Am J Aquat Res 40, 448-452. 